\title{
Response of rocky shore communities to anthropogenic pressures in Albania (Mediterranean Sea): Ecological status assessment through the CARLIT method
}

\author{
Aurélie Blanfuné $^{\mathrm{a}, *}$, Charles François Boudouresque ${ }^{\mathrm{a}}$, Marc Verlaque ${ }^{\mathrm{a}}$, Sajmir Beqiraj ${ }^{\mathrm{b}}$, Lefter Kashta ${ }^{\mathrm{c}}$, \\ Ina Nasto ${ }^{\mathrm{d}}$, Stela Ruci ${ }^{\mathrm{b}}$, Thierry Thibaut ${ }^{\mathrm{a}}$ \\ a Aix Marseille Université, CNRS/INSU, Université de Toulon, IRD, Mediterranean Institute of Oceanography (MIO), UM 110, 13288 Marseille, France \\ b Biology Department, Faculty of Natural Sciences, University of Tirana, Bulevardi Zog I, 25/1, 1001 Tirana, Albania \\ c Research Center for Flora and Fauna, Faculty of Natural Sciences, University of Tirana, Bulevardi Zog I, 25/1, 1001 Tirana, Albania \\ d Biology Department, Faculty of Technical Sciences, University of Vlora "Ismail Qemali", Sheshi Pavaresia, Vlore, Albania
}

\section{A R T I C L E I N F O}

\section{Article history:}

Received 5 April 2016

Received in revised form 6 May 2016

Accepted 14 May 2016

Available online $\mathrm{xxxx}$

\section{Keywords:}

Albania

Anthropogenic pressures

MPA

CARLIT index

Cystoseira amentacea

Lithophyllum byssoides

Mediterranean

\begin{abstract}
A B S T R A C T
The lower mid-littoral and shallow subtidal communities were studied in the district of Vlora (Albania), three years after the establishment of a Marine Protected Area, with particular attention to the long-lived species. The bioconstructions built in the mid-littoral zone by the calcified rhodobiont Lithophyllum byssoides were in poor condition and sometimes even dead. In contrast, the brown alga Cystoseira amentacea constituted lush stands. For assessing the ecological status of the studied area, the CARLIT method, based upon macroalgal communities, was applied. The observed range of ecological status was wide ('high' through 'bad') and was overall among the lowest assessed to date in the Mediterranean Sea. The occurrence of extensive sea-urchin barrengrounds, though not taken into consideration by the CARLIT index, confirmed the poor condition of large sectors of the study area. Overall, the CARLIT index is well correlated with anthropogenic pressures, as assessed by the LUSI index.
\end{abstract}

@ 2016 Published by Elsevier Ltd.

\section{Introduction}

The Mediterranean Sea is a hotspot of marine biodiversity that is under siege due to high demographic pressure, a high percentage of worldwide shipping and tourism and the highest worldwide rate of biological invasions (Bianchi and Morri, 2000; Galil, 2000; Boudouresque and Verlaque, 2002; Boudouresque, 2004; Lotze et al., 2006; Coll et al., 2010, 2012; Lejeusne et al., 2010; Zenetos et al., 2010; UNEP/MAP, 2012; Bianchi et al., 2014; Giakoumi et al., 2015). Different pressures act over time and in unison, with possible synergy effects, to affect the species, the ecosystems and their ability to deliver ecosystem services (e.g. Worm et al., 2006; Halpern et al., 2008; Waycott et al., 2009).

Within the framework of the Water Framework Directive (WFD, 2000/60/EC) (E.C., 2000) of the European Union (EU), several indices based upon marine indicator species have been proposed to assess the ecological status of coastal water bodies, e.g. the CCO index (Cover, Characteristic species, Opportunistic species), based upon intertidal seaweeds along the European Atlantic coasts (Ar et al., 2016) and the EEI (Ecological Evaluation Index, based upon macroalgae), PREI (Posidonia oceanica Rapid Easy Index, based upon the P. oceanica seagrass), RMaQUI (based upon lagoon macrophytes), MAES (for mesophotic

\footnotetext{
* Corresponding author.

E-mail address: aurelie.blanfune-thibaut@mio.osupytheas.fr (A. Blanfuné).
}

assemblages between 50 and $150 \mathrm{~m}$ depth, based upon ROV-imagery) and CARLIT (Cartography Littoral), based upon mid-littoral and shallow water species for the Mediterranean coasts (Orfanidis et al., 2003; Ballesteros et al., 2007; Sfriso et al., 2007; Gobert et al., 2009, Nikolić et al., 2013; Cánovas et al., 2016). The indicator species of good ecological status used for the CARLIT index (Ballesteros et al., 2007) are the longlived species, i.e. seagrasses, Lithophyllum byssoides (Lamarck) Foslie (Rhodobionta, Archaeplastida) and Cystoseira spp. (Phaeophyceae, Stramenopiles), which are usually regarded as sensitive to pollution and coastal development. For this reason, they were included within the Berne Convention on the conservation of European wildlife and natural habitats (Appendix I: strictly protected flora species) (Council of Europe, 1979) and the Barcelona Convention for the protection of the marine environment and the coastal regions of the Mediterranean (Annex II: 'Endangered or threatened species that the Parties shall manage with the aim of maintaining them in a favourable state of conservation') (Barcelona Convention, 1976, 1996).

Lithophyllum byssoides (synonym Lithophyllum lichenoides) is a calcified red alga that thrives exclusively within a narrow vertical range a few centimetres above the mean sea-level (lower mid-littoral zone sensu Pérès, 1982). It is the ecosystem engineer of the Lithophylletum lichenoidis Giaccone 1993 association (Giaccone et al., 1993), which harbours both marine and terrestrial taxa (Molinier, 1958, 1960). Its midlittoral location exposes it to sea-surface pollution. Under suitable 
environmental conditions (unpolluted, dim light and high hydrodynamics), it can constitute large bioconstructions referred to as Lithophyllum byssoides rims (Picard, 1954; Blanc and Molinier, 1955; Ballesteros, 1984; Laborel et al., 1994a). Due to the very narrow vertical distribution range $( \pm 10 \mathrm{~cm}$ ) of $L$. byssoides and to its slow growth rate (Faivre et al., 2013; Thibaut et al., 2013), such bioconstructions require a long period of relative stabilisation of the sea-level to settle. Consequently, L. byssoides rims are valuable indicators of near-stable or slowly rising sea-level and high sea-water quality over long periods (Laborel et al., 1983, 1993, 1994b; Morhange et al., 1992; Morhange, 1994; Laborel and Laborel-Deguen, 1996; Bressan et al., 2001; Faivre et al., 2013).

Species of the genus Cystoseira C. Agardh (Phaeophyceae, Stramenopiles) are canopy forming brown algae dominating several assemblages from the subtidal fringe $(<1 \mathrm{~m}$ below the mean sea level) down to the lower limit of the euphotic zone (infralittoral and circalittoral zone sensu Pérès, 1982) (Feldmann, 1937; Molinier, 1960; Pignatti, 1962; Verlaque, 1987; Ballesteros, 1988, 1990a, 1990b; Giaccone et al., 1994). The zonation and the extension of these assemblages are under the control of a range of environmental conditions (light, temperature, hydrodynamics, water quality and grazing) (Sauvageau, 1912; Ollivier, 1929; Vergés et al., 2009). Among the Cystoseira species, Cystoseira amentacea [previously referred to as Cystoseira stricta (Montagne) Sauvageau and Cystoseira spicata Ercegović] is a species widely distributed in the Mediterranean Sea. It belongs, like Cystoseira mediterranea Sauvageau and Cystoseira tamariscifolia (Hudson) Papenfuss, to a morphological group restricted to the subtidal fringe, (Sauvageau, 1912; Feldmann, 1937; Ribera et al., 1992). Cystoseira amentacea is the ecosystem engineer of the Cystoseiretum stricta Molinier, 1958 association, which harbours hundreds of species and can occupy extensive zones of wave-exposed shallow hard substrates (Molinier, 1960; Bellan-Santini, 1968; Boudouresque, 1971a, 1971b).

Albania has about $427 \mathrm{~km}$ of coastline facing the Adriatic and Ionian seas, within the Mediterranean Sea. The marine environment of the Albania coast varies widely from north to south. The Adriatic northern part is dominated by shallow waters, sandy beaches, sandspits, wetlands and lagoons, whereas the Ionian southern part is a rugged rocky coast with high reliefs and caves (Tilot and Jeudy de Grissac, 1994). Located in the middle part of Albania, the city of Vlora is the second largest port (for trade and fisheries) in the country and one of the most attractive tourism resorts in the eastern part of the Mediterranean Sea (Fraschetti et al., 2011). The resident population is about 150,000 inhabitants and about 2 million tourists were accommodated in 2008 (INSTAT, 2008). The north and south coasts of the Bay of Vlora are occupied by extensive beaches. Facing Vlora, Sazani Island and the Karaburuni Peninsula are composed mainly of Cretaceous limestone rocks. In contrast with Vlora, the rural population of Sazani Island and the Karaburuni Peninsula is low, with 5-20 inhabitants $\mathrm{km}^{-2}$. Sazani Island is military territory and Karaburuni Peninsula was declared a natural reserve in 1966. In April 2010, the coastal and marine area of Sazani Island and the Karaburuni Peninsula were raised to the status of Marine Protected Area (MPA), which is the first and the only existing MPA in Albania (Kashta et al., 2011).

Only a very few data sets regarding the presence, abundance and patterns of distribution of marine species and communities were available in this area, these being 3 seaweed checklists (Kashta, 1986; Kupe and Miho, 2006; Antolić et al., 2010), an in-depth study of the genus Cystoseira (Ercegović, 1952) and a general assessment of biodiversity and communities (Fraschetti et al., 2011).

The aim of the present study was to assess (i) the distribution and state of conservation of the Lithophyllum byssoides rims, the Cystoseira amentacea stands and shallow subtidal communities (ii) the ecological status of coastal waters of the region by means of the CARLIT method, especially along the coastline of Sazani Island and Karaburuni Peninsula, after the establishment of the MPA, (iii) the comparison between two methods of calculation of the CARLIT index (Ballesteros et al., 2007;
Nikolić et al., 2013), and (iv) the congruence of the CARLIT index versus two proxies of anthropogenic pressure (Lopez y Royo et al., 2009; Flo et al., 2011).

\section{Materials and methods}

\subsection{Sampling sites}

The study was conducted in May 2013 in the district of Vlora (Albania, Mediterranean Sea). Most of the study area was located within the MPA of Sazani Island and the Karaburuni Peninsula (Fig. 1). The shore south to Orso Bay, though belonging to the MPA, was not explored. Although $L$. byssoides and C. amentacea are perennial and long-lived species that can be observed year round, late spring is the most suitable period for such field work, as erect branches of $C$. amentacea are then fully developed.

\subsection{Identifying ecological regions in the studied area}

No coastal water bodies have been previously delineated in Albania, a country which does not belong to the $\mathrm{EU}$, and is not bound to apply the European WFD requirements. We therefore undertook the following delineation by coastal water bodies according to the ridgelines watershed: the western and northern shores of Karaburuni Peninsula, the eastern shore of Karaburuni Peninsula and the southern and eastern shores of the Bay of Vlora, the western and the eastern shores of Sazani Island (Fig. 1).

\subsection{Mapping of lower mid-littoral and shallow subtidal communities}

The geomorphological characteristics of the shoreline were drawn on black and white A3 format aerial photographs from Google Earth ${ }^{\circledR}$. The scale was 1:2500. Three observers worked on board a small boat (length $5 \mathrm{~m}$ ) moving at low speed ( 3 to $6 \mathrm{~km} \mathrm{~h}^{-1}$ ) a few metres from the shore. The species and communities were entirely mapped. Observations were entered within a Geographical Information System (GIS) database (ArcGis10®), allowing the extraction of latitude and longitude of each location, using the coordinate system WGS-1984-UTM-zone$34 \mathrm{~N}$.

The Lithophyllum byssoides rims of measurable size (i.e. at least $0.2-$ $\mathrm{m}$ width and 1-m long) and with a distinct overhang were exhaustively mapped and their vitality was visually assessed (alive rims vs dead).

Among the shallow subtidal communities, down to 2-m depth, we mapped Cystoseira amentacea, Cystoseira compressa, Corallina caespitosa, Mytilus galloprovincialis, the mosaic of stands of other erect macroalgae and the barren grounds of encrusting corallines with the sea urchins Paracentrotus lividus (Lamarck, 1816) and Arbacia lixula (Linnaeus, 1758). For taxonomic and nomenclatural purposes, the worldwide electronic database algaebase.org (Guiry and Guiry, 2015) was followed.

\subsection{Ecological status assessment}

The ecological status of coastal water bodies of the study are was assessed by means of the CARLIT method (Ballesteros et al. (2007). The CARLIT method is based upon the mapping of geomorphological characteristics obtained in the field (slope, morphology and natural/artificial substrate) and some mid-littoral and shallow subtidal species and communities of the rocky shoreline.

Six relevant geomorphological situations identified by Ballesteros et al. (2007), according to the coastline morphology and natural/artificial substrates (Table S1), were mapped.

The species and communities taken into account, according to a decreasing level of sensitivity (SL, from 20 , very sensitive, to 1 , not sensitive) to disturbance, are listed in Table S2.

For each geomorphological situation, the length of the coast occupied by each community type was measured and the ecological quality 


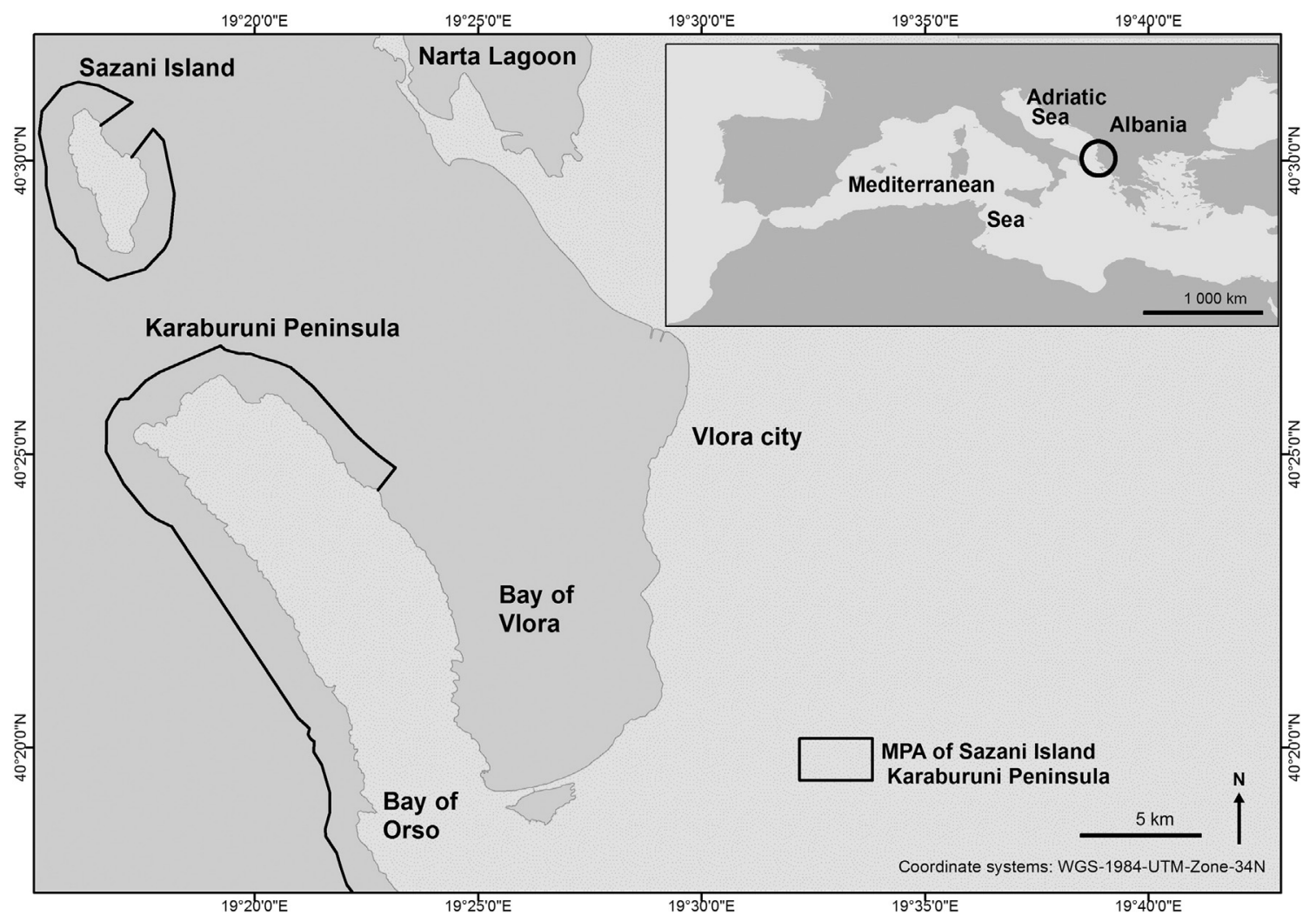

Fig. 1. The study site (district of Vlora) with the location of the Sazani Island and Karaburuni Peninsula MPA. Albania in the Mediterranean basin (above right).

value (EQ) was calculated using the formula:

$\mathrm{EQ}_{\mathrm{ssi}}=\sum\left(1_{\mathrm{j}} * \mathrm{SL}_{\mathrm{j}}\right) / \sum 1_{\mathrm{j}}$

where $\mathrm{i}$ is the geomorphological situation; $\mathrm{EQ}_{\mathrm{ssi}}$ is the ecological quality value of the geomorphological situation $i$; $l_{j}$ is the length of the coastline with the species/community $\mathrm{j}, \mathrm{SL}_{\mathrm{j}}$ is the sensitivity level of the species/ community $\mathrm{j}$ (Table S2) and $\sum \mathrm{l}_{\mathrm{j}}$ is the total length of the coastline occupied by the geomorphological situation $\mathrm{i}$.

According to the WFD, the ecological status of a coastal water body has to be expressed in terms of ecological quality ratios (EQR). This ratio indicates the relationship between the value of the biological parameters (here species and communities) recorded for a given coastal water body and the value for these parameters in the reference conditions applicable to this body.

The EQR (Ecological Quality Ratio) of the geomorphological situation of a coast is calculated as the ratio between the EQ obtained $\left(\mathrm{EQ}_{\mathrm{ssi}}\right)$ and the EQ obtained in the reference sites corresponding to the same 'geomorphological situation' ( $\mathrm{EQ}_{\mathrm{rsi}}$ ) (Table S1). Therefore, the EQR of a coast corresponding to a coastal water body is calculated according to the following formula:

$\mathrm{EQR}=\left(\sum\left[\left(\mathrm{EQ}_{\mathrm{ssi}} / \mathrm{EQ}_{\mathrm{rsi}}\right) * \mathrm{1}_{\mathrm{i}}\right]\right) / \sum \mathrm{l}_{\mathrm{i}}$

where $\mathrm{i}$ is the geomorphological situation; $\mathrm{EQ}_{\mathrm{ssi}}$ is the EQ at the study site for the geomorphological situation $\mathrm{i} ; \mathrm{EQ}_{\mathrm{rsi}}$ is the $\mathrm{EQ}$ at the reference sites for the geomorphological situation $i ; l_{i}$ is the coastal length occupied by the geomorphological situation $i\left(l_{i}=\sum l_{j}\right)$ and $\sum l_{i}$ is the total length of the coastline of the coastal water body $\left(\sum \mathrm{li}=\sum \sum \mathrm{l}_{\mathrm{j}}\right.$ ).

The EQR is expressed as a numerical value between 0 and 1 . The ecological status of a coastal water body is defined as follows:

\begin{tabular}{ll}
\hline EQR & Ecological status \\
\hline 1 to $>0.75$ & High \\
0.75 to $>0.60$ & Good \\
0.60 to $>0.40$ & Moderate \\
0.40 to $>0.25$ & Poor \\
0.25 to 0.0 & Bad \\
\hline
\end{tabular}

Nikolić et al. (2013) developed a slightly modified CARLIT index for the eastern Adriatic Sea. The equations and the rationale are the same as described by Ballesteros et al. (2007). The differences lie in the geomorphologically relevant situations (Table S3) and in some species and communities, in their sensitivity levels (Table S4). The two methods of calculation of the CARLIT Index have been applied to the same database and water bodies.

\subsection{Assessment of anthropogenic pressures}

A water quality assessment of coastal water bodies must be done in relation to anthropogenic pressures. The assessment of known pressures that could affect the water quality within the study area was performed using the land use pressures according to CORINE Land Cover information system 2000-2006 (Büttner et al., 2004; CORINE land cover, 2006). We considered maps of the coast spanning a $1 \mathrm{~km}$ wide strip along each coastal water body: the western and northern shores of Karaburuni Peninsula, the eastern shore of Karaburuni Peninsula, the southern and eastern shores of the Bay of Vlora, and the western and the eastern shores of Sazani Island.

Land uses simplified index (LUSI) was calculated according to Flo et al. (2011). Assessment of anthropogenic pressures on the coastal zone by calculating the LUSI index using the publicly available data is described in UNEP/MAP (2011). In the present study, we used the adaptation of LUSI index proposed by Nikolić et al. (2013) (Table S5). 
For each coastal water body all scores for pressure were summed. Afterwards, a correction was applied to this sum in order to take into account the degree of confinement that could emphasize or diminish the effect of these pressures on the water body. Depending on the concave, convex or straight shape of the coastal line, the sum was multiplied by the correction factor $1.25,0.75$ or 1.00 (Table S5).

LUSI Index $=(\mathrm{A}+\mathrm{B}+\mathrm{C}+\mathrm{D}) * \mathrm{E}$.

In addition to the LUSI index, which provides a quantitative value assessing the anthropogenic pressures, we also tested the qualitative index proposed by Lopez y Royo et al. (2009) based on the surface area occupied by urban, agricultural and industrial activities using the Google-Earth images (for further details see Lopez y Royo et al., 2009).

\section{Results}

\subsection{Distribution and state of conservation of Lithophyllum byssoides rims}

In the lower mid-littoral zone, L. byssoides was widespread. In 96 localities, it has built bioconstructions larger than $0.2-\mathrm{m}$ wide and $1-\mathrm{m}$ long for a cumulative length of $\sim 2.5 \mathrm{~km}$ for a total coastline length of $\sim 68 \mathrm{~km}$, which represents $3.6 \%$ of the rocky coastline (Fig. 2, Table S6). Most of the L. byssoides rims were facing W and NW (Fig. 2). Although large $L$. byssoides rims, up to $\sim 1$-m wide, were previously reported in the study area (Tilot and Jeudy de Grissac, 1994), most L. byssoides rims were relatively narrow with a width of $<0.5 \mathrm{~m}$.

At Sazani Island, especially in its southern part, a number of $L$. byssoides rims were in very poor condition (Fig. 2: arrows). They were located at a relatively low tide level, resulting in an unusually frequent covering by the sea water, even under calm conditions. They were deeply bored by holes and a network of blow-holes, making some of them a veritable lacework of calcareous bioconstruction. Lastly, their upper side was densely coated with perennial macroalgae, especially Corallina caespitosa, a species previously misidentified as $C$. mediterranea or $C$. elongata, and commonly used as a proxy of the upper limit of the subtidal zone. The vitality of these $L$. byssoides rims was considered as nil and their status as dead (fossil L. byssoides rims). In contrast, at Karaburuni Peninsula and in the north of Sazani, the upper side of the rim showed a more or less continuous cover of living L. byssoides, and the rims were considered as alive (Fig. 2: solid circles). However, with regard to the fossil $L$. byssoides rims, they were often perforated by a network of holes, so their health status was considered as intermediate.

\subsection{Distribution of Cystoseira amentacea stands and shallow subtidal communities}

Cystoseira amentacea is well-distributed on the western and northern sides of the Karaburuni Peninsula and the western part of Sazani Island. On the eastern side of the Karaburuni Peninsula, C. amentacea populations are less continuous and are replaced southwards by $C$. compressa (Fig. 3).

Beyond the $L$. byssoides rims and the $C$. amentacea stands, either barren-grounds or stands of erect macroalgae were present, except in front of the totally artificialized north-eastern part of Sazani Island that is occupied by the concrete bunkers and reclamations of a military base, with no macroscopic marine stands. Barren-grounds were characterized by encrusting corallines and sea urchins, Paracentrotus lividus and Arbacia lixula. These barren-grounds thrived from $\sim 30 \mathrm{~cm}$ below the subtidal fringe down to at least $2 \mathrm{~m}$ depth. They occurred on the eastern side of the Karaburuni Peninsula and the western side of Sazani Island (Fig. 3). Along the rocky shores of the southernmost part of the Bay of Vlora, the barren-grounds extended up to the sea surface. Stands of erect macroalgae consisted in a patchwork of species, mainly Corallina caespitosa, Halopteris scoparia (Linnaeus) Sauvageau, Padina sp., Dictyota spp. and four species of the genus Cystoseira: C. barbata

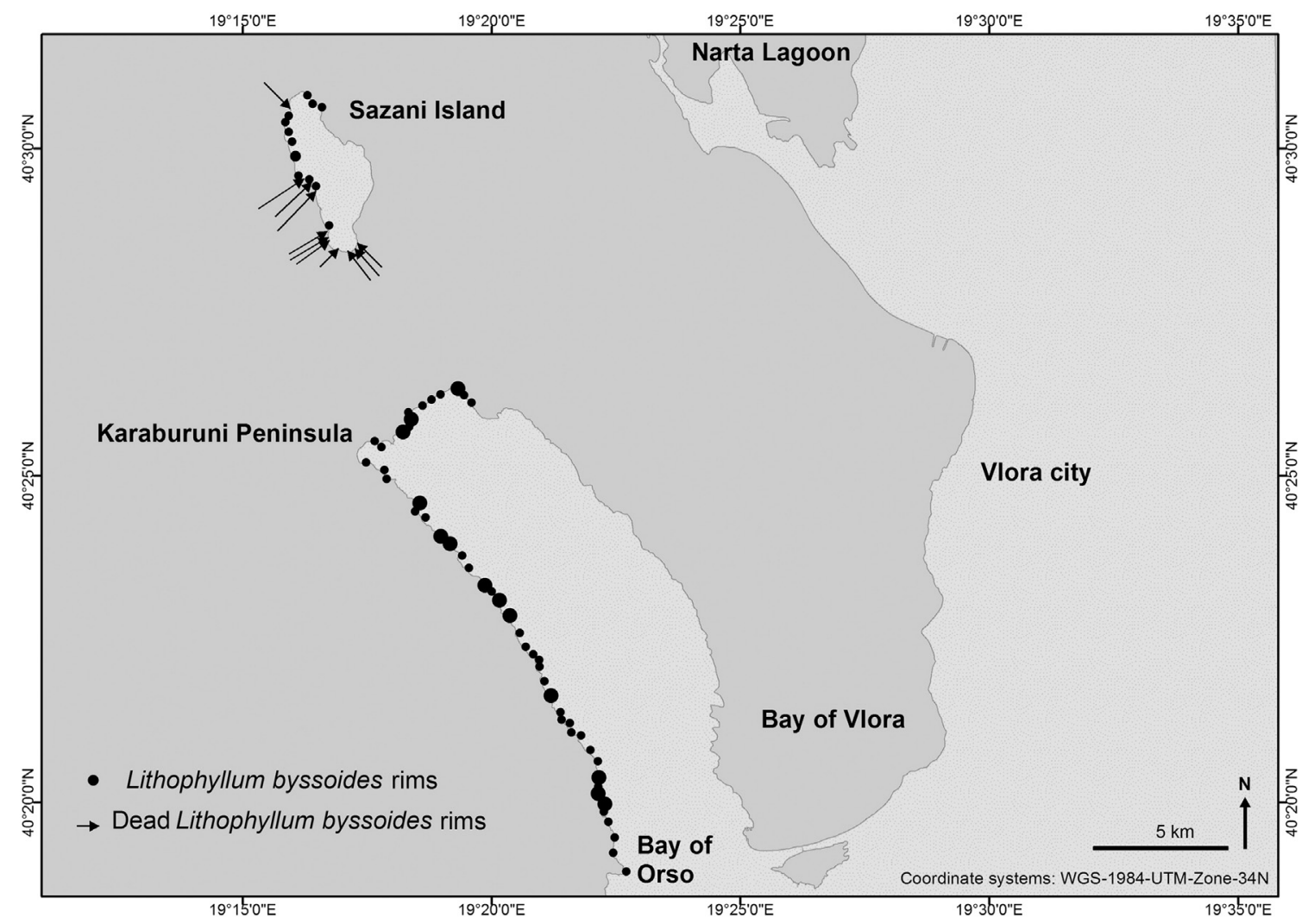

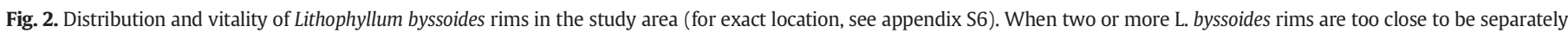
represented, they are depicted by a larger solid circle. 


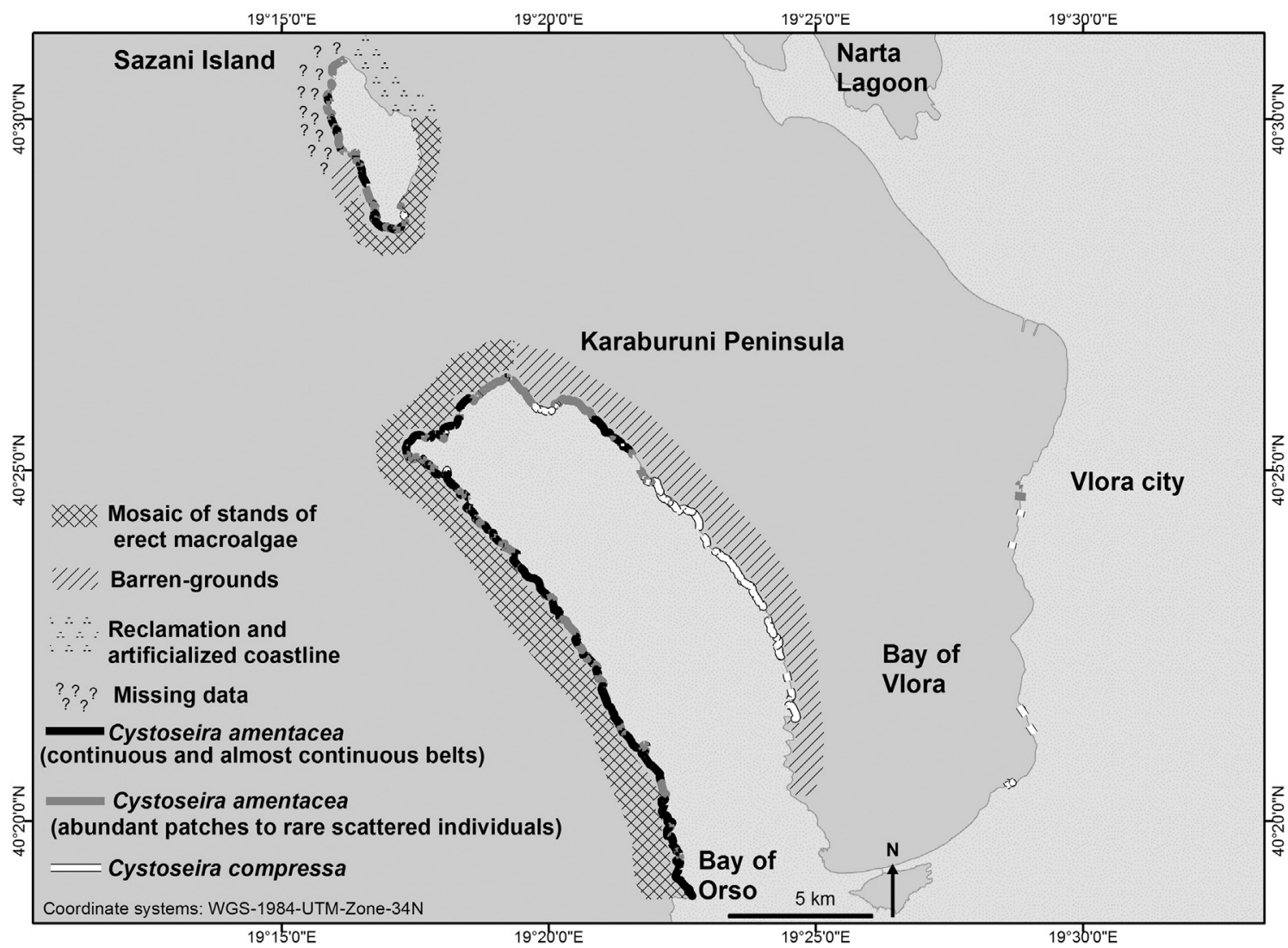

Fig. 3. Distribution of Cystoseira amentacea, C. compressa, mosaic stands of erect macroalgae, barren-grounds and reclamation and artificialized coastline in the study area.

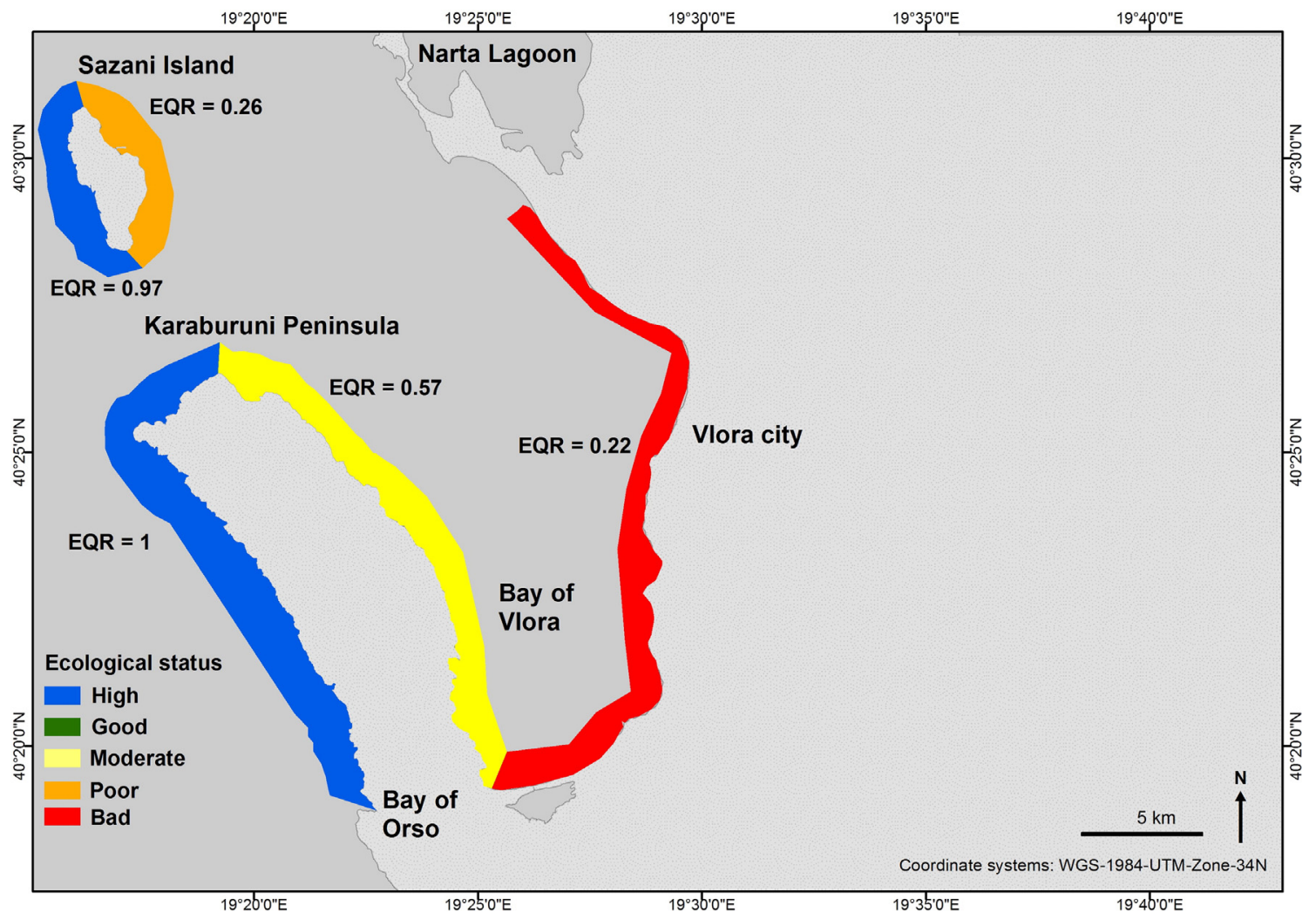

Fig. 4. Ecological Quality Ratio (EQR) and ecological status of the different coastal water bodies of the study area in 2013, according to the Ballesteros et al. (2007) CARLIT method. 
(Stackhouse) C. Agardh, C. crinita, Cystoseira crinitophylla Ercegović, C. corniculata (Turner) Zanardini. Large populations of Cystoseira foeniculacea (Linnaeus) Greville f. foeniculacea and C. barbata were found in rock pools close to Narta Lagoon, at the northern mouth of the Bay of Vlora. Lastly, a drift specimen of $C$. foeniculacea f. latiramosa (Ercegović) A. Gómez Garreta, M.C. Barceló, M.A. Ribera \& J.R. Lluch was found in a fish net, at Vlora harbour, which indicates its occurrence in the study area. No individual of Fucus virsoides was found during our field surveys.

\subsection{Ecological status and anthropogenic pressures}

The ecological status of the northern and western shores of the Karaburuni Peninsula and of the western shore of Sazani Island was high. In contrast, the three other coastal water bodies fell within the bad to moderate ecological status range (Fig. 4, Table 1). Except for one coastal water body (eastern shore of Karaburuni Peninsula), the ecological status was identical whatever the CARLIT index calculation used (Ballesteros et al., 2007 versus Nikolić et al., 2013); however, the Nikolić et al. (2013) EQR was often higher (Table 1).

In order to validate the use of the CARLIT index, the EQR values (calculated for both CARLIT methods) were compared with values of LUSI (Land Uses Simplified Index) and Lopez y Royo et al. (2009) pressure index obtained for each coastal water body (Table 1 ). The calculated EQR values were significantly correlated with the LUSI index $(r=$ 0.85, with Ballesteros et al., 2007 method; $r=0.87$, with Nikolić et al., 2013 method; both being significant, $\mathrm{p}>0.001$ ) confirming a good response of the CARLIT method to the different levels of disturbance.

It is worth noting that, in contrast, the Lopez y Royo et al. (2009)pressure index was more roughly linked to the calculated EQR values than the LUSI index (for the both CARLIT methods) (Table 1), indicating the poorer efficiency of the former.

\section{Discussion}

The lower mid-littoral and shallow subtidal communities (0-2 m depth) were studied in the district of Vlora (Albania), three years after the establishment of a Marine Protected Area.

In the lower mid-littoral zone, $L$. byssoides rims represented $3.6 \%$ of the coastline, a significant value although lower than some percentages previously measured in the western Mediterranean (Table 2). Most of the $L$. byssoides rims were facing $\mathrm{W}$ and NW, which is consistent with the wave exposure and the dim light conditions required by the species and the distribution described in other Mediterranean regions (Molinier, 1960; Sicsic, 1967; Bianconi et al., 1987). They were narrow ( $<0.5 \mathrm{~m}$ wide) while much wider $L$. byssoides rims have been described in the Mediterranean Sea (Bianconi et al., 1987; Laborel, 1987; Monbailliu and Torre, 1990; Laborel et al., 1994a; Harmelin et al., 1996; Boudouresque, 2003; Faivre et al., 2013). Many L. byssoides rims were dead or in very bad state with frequently a network of holes. Several possible causes of regression of $L$. byssoides rims have been reported in the literature, namely trampling, sea surface pollution and the worldwide rise in sea-level (Verlaque, 2010; Faivre et al., 2013; Thibaut et al., 2013). In the study area, the absence of wide L. byssoides rims, the steep shore profile and the difficulties of berthing or reaching these bioconstructions from the land, mean that trampling can be ruled out as a possible cause of degradation. Pollution which enhances the development of bioeroder organisms and the formation of holes (Laborel, 1987; Morhange et al., 1992; Laborel et al., 1994a, 1994b; Riggio et al., 1994; Boudouresque, 2003), is a better candidate because the waters of the Bay of Vlora are impacted by inputs of numerous pollutants from unmanaged expanding urbanization, the navy base at Karaburuni, maritime traffic, environmentally uncontrolled touristic pressure and sewage from a hydrochloric acid factory (Tilot and Jeudy de Grissac, 1994; Fraschetti et al., 2011). Finally, all Mediterranean L. byssoides rims were formed during the stabilisation or the slow rising of the sea-level throughout the Little Ice Age (LIA) (late 13th through early 19th centuries). The current acceleration of the worldwide rise in sealevel (3.3 $\mathrm{mm} \mathrm{a}^{-1}$ between 1993 and 2009; Nicholls and Cazenave, 2010) would appear to be too rapid for the growth capacities of $L$. byssoides rims (Verlaque, 2010; Faivre et al., 2013; Thibaut et al., 2013). In the study region, the occurrence of subtidal species on the upper side of the lowest $L$. byssoides rims agrees well with this hypothesis. Similar submersion of $L$. byssoides rims has already been reported in the central Adriatic Sea (Faivre et al., 2013) and in the northwestern Mediterranean basin (Thibaut et al., 2013). The co-occurrence, in the same area, of L. byssoides rims in good and bad conditions could be due to different wave exposure; under highly exposed conditions, the rims are located higher, and are therefore less vulnerable to the sea level rise, than under less exposed conditions.

Cystoseira amentacea stands were well distributed in the study area, especially on the western and northern shores of the Karaburuni Peninsula and the western part of Sazani Island. The species has long been considered as highly sensitive to anthropogenic pressures, e.g. pollution, resulting in dramatic regression events (Bellan-Santini, 1966; Janssens et al., 1993; Soltan et al., 2001; Boudouresque, 2003). In the southern Adriatic Sea, Falace et al. (2010) mention local regressions near Torre Guaceto but also extensive populations forming a continuous belt along the Apulian coast. In fact, an extensive mapping of northwestern Mediterranean populations (Southern France and Corsica) revealed that $C$. amentacea still formed an almost continuous belt in most suitable habitats, despite pollution and coastal development (Thibaut et al., $2007,2014,2015)$. The disappearances of $C$. amentacea stands were only restricted to coastal artificialized areas (harbours, reclamations) and waters severely polluted by urban and industrial sewage. Accordingly, continuous or almost continuous stands of $C$. amentacea observed in some parts of the study area, although indicating that the water body was not degraded, could not be considered per se as a proxy of pristine waters.

In 1992, some specimens of the mid-littoral fucoid Fucus virsoides J. Agardh, an Adriatic endemic species common in the northern part of the Sea (Munda, 1972), were reported in the Bay of Vlora (Kashta, 1986, 1992). This record constituted the southern limit of distribution of the species. No individual of $F$. virsoides was found during our field survey, as already reported by Kashta (1995-1996), which confirms the general decline of the species in the mid-Adriatic Sea (Mačić, 2006; Falace et al., 2010).

Table 1

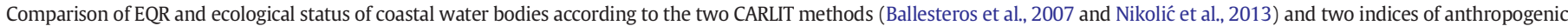
pressure: LUSI (calculation method from Nikolić et al., 2013) and the Lopez y Royo et al. (2009) pressure index.

\begin{tabular}{|c|c|c|c|c|c|c|}
\hline & \multicolumn{2}{|c|}{ Ballesteros et al., 2007} & \multicolumn{2}{|c|}{ Nikolić et al., 2013} & \multirow[b]{2}{*}{ LUSI index } & \multirow[b]{2}{*}{ Lopez y Royo et al. (2009) pressure index } \\
\hline & $\mathrm{EQR}$ & Ecological status & $\mathrm{EQR}$ & Ecological status & & \\
\hline Western shore of Sazani Island & 0.97 & High & 1.00 & High & 0 & No pressure \\
\hline Eastern shore of Sazani Island & 0.26 & Poor & 0.29 & Poor & 4 & Moderate pressure \\
\hline Western and northern shores of Karaburuni Peninsula & 1.00 & High & 1.00 & High & 0 & No pressure \\
\hline Eastern shore of Karaburuni Peninsula & 0.57 & Moderate & 0.62 & Good & 2 & High pressure \\
\hline Southern and eastern shores of the Bay of Vlora & 0.22 & Bad & 0.22 & Bad & 10 & High pressure \\
\hline
\end{tabular}


Table 2

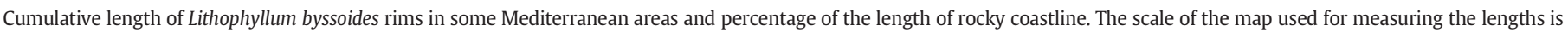
specified.

\begin{tabular}{|c|c|c|c|c|c|}
\hline Area & $\begin{array}{l}\text { Region or } \\
\text { country }\end{array}$ & $\begin{array}{l}\text { Cumulative length of } \\
\text { rims }\end{array}$ & $\begin{array}{l}\text { Length of the rocky coastline (scale of } \\
\text { the map) }\end{array}$ & $\begin{array}{l}\text { Percentage of } \\
\text { rims }\end{array}$ & Reference \\
\hline Sazani Island and Karaburuni Peninsula MPA & Albania & $\sim 2500 \mathrm{~m}$ & $68,376(1: 2500)$ & $3.6 \%$ & This study \\
\hline San Fiurenzu Gulf & $\begin{array}{l}\text { Northern } \\
\text { Corsica }\end{array}$ & $0 \mathrm{~m}$ & $17,804 \mathrm{~m}(1: 2500)$ & $0.0 \%$ & $\begin{array}{l}\text { Thibaut and Blanfuné, } \\
2014\end{array}$ \\
\hline Scàndula MPA (Punta Nera to Punta Scàndula) & $\begin{array}{l}\text { Western } \\
\text { Corsica }\end{array}$ & $\sim 7980 \mathrm{~m}^{\mathrm{a}}$ & $\sim 28,500 \mathrm{~m}(1: 5000)$ & $28 \%$ & Bianconi et al., 1987 \\
\hline Monte Carlo to Cap d'Ail & French Riviera & $14 \mathrm{~m}$ & $3500 \mathrm{~m}(1: 2500)$ & $0.4 \%$ & $\begin{array}{l}\text { Thibaut and Blanfuné, } \\
2014\end{array}$ \\
\hline Saint-Raphaël to West Sainte-Maxime & $\begin{array}{l}\text { Eastern } \\
\text { Provence }\end{array}$ & $15 \mathrm{~m}$ & $7500 \mathrm{~m}(1: 2500)$ & $0.2 \%$ & $\begin{array}{l}\text { Thibaut and Blanfuné, } \\
2014\end{array}$ \\
\hline $\begin{array}{l}\text { Cap-Croisette to Endoume and Frioul Islands } \\
\text { (Marseille) }\end{array}$ & $\begin{array}{l}\text { Western } \\
\text { Provence }\end{array}$ & $6618 \mathrm{~m}$ & $47,271 \mathrm{~m}(1: 2500)$ & $14.0 \%$ & $\begin{array}{l}\text { Thibaut and Blanfuné, } \\
2014\end{array}$ \\
\hline Racou to Cerbère & $\begin{array}{l}\text { French } \\
\text { Catalonia }\end{array}$ & $1512 \mathrm{~m}$ & $50,400 \mathrm{~m}(1: 2500)$ & $3.0 \%$ & $\begin{array}{l}\text { Thibaut and Blanfuné, } \\
2014\end{array}$ \\
\hline
\end{tabular}

a In fact, not the cumulative length of rims, but that of 50-m segments encompassing a L. byssoides rim.

With regard to the large areas covered with barren-grounds, the total lack of environmental management is clearly to be blamed. The regime shift from marine forests to barren-grounds devoid of erect macroalgae is generally linked to the overexploitation of predatory fish, which gives rise to the rapid expansion of herbivorous sea urchin populations (Sala et al., 1998, 2012; Steneck, 1998; Boudouresque and Verlaque, 2013; Ling et al., 2015). Overfishing, not only using fishing nets and trawling but also by means of the illegal use of explosives, and the illegal breaking of shallow water rocks for date mussel Lithophaga lithophaga (Linnaeus, 1758) extraction, have already been denounced by Tilot and Jeudy de Grissac (1994) and Fraschetti et al. (2011). These illegal harvesting methods are still widely are still widespread, according to fishers themselves and to a student involved in the establishment of the MPA (Simon Moncelon, pers. comm.). Such destructive practices are known to have a dramatic impact on marine Mediterranean communities (Fanelli et al., 1994; Fraschetti et al., 2001; Guidetti and Boero, 2004; Devescovi et al., 2005). In addition, the sedimentary inputs from the Vjosa River, which runs north to Vlora (although the cyclonic general surface circulation flows northwards; Orlić et al., 1992), the pollution from the urban sewer of the Vlora city (Maiorano et al., 2011) and the current increase in tourism pressure might be related with the worsening of coastal water quality in the Bay of Vlora.

The CARLIT index is used in most of the EU Mediterranean countries: Spain, France, Italy, Malta and Croatia (Ballesteros et al., 2007; Buia et al., 2007; Mangialajo et al., 2007; Omrane et al., 2010; Blanfuné et al., 2011; Sfriso and Facca, 2011; Bermejo et al., 2012, 2013; Nikolić et al., 2013; Ferrigno et al., 2014; Thibaut and Blanfuné, 2014). It is here applied for the first time in Albania, a non-EU country. The broad acceptance of this methodology for the assessment of the ecological status of coastal water bodies is due to the fact that (i) it is not destructive (no collection of species required); (ii) the mapping only concerns intertidal and very shallow marine habitats (no SCUBA diving required); (iii) large coastal stretches can be exhaustively explored; (iv) the considered taxa are relatively easy to identify by well-trained observers; (v) the CARLIT index is robust, with the ecological status of a given coastline congruent at a long time scale (Cavallo et al., 2016; Torras et al., 2016).

The ecological status assessed by the CARLIT method was high for the northern and western shores of the Karaburuni Peninsula and the western shore of Sazani Island. In contrast, the three other coastal water bodies fell within the bad to moderate ecological status range. Nikolić et al. (2013) proposed some improvements to the CARLIT method, e.g. a change in the species taken into account and a local adaptation of Ecological Quality values of the relevant geomorphological situation. Measuring the substrate slope for each habitat and community type, as suggested by the authors, was time-consuming and adopting their improvements only had a slight effect on the final assessment.

Overall, the ecological status of the study area was among the worst recorded in the areas already studied in the western Mediterranean basin and the Adriatic Sea (Table 3). Overall, despite the establishment of a MPA in 2010, the ecological status of a large part of the area was still poor or bad in 2013. No improvement was apparent when compared with the 2007 situation (Fraschetti et al., 2011), rather to some degree a decline in status. The same conclusion has been drawn for this area through an assessment of macrobenthos and fish, carried out in June 2015 (Samjir Bekiraj and Lefter Kashta, unpublished data).

The ecological status of the study area exhibited a good correlation with the LUSI index as a proxy of anthropogenic pressures, as previously evidenced by Bermejo et al. (2013) and Nikolić et al. (2013). In contrast, the Lopez y Royo et al. (2009) pressure index appeared not to be suitable at coastal water body scale.

In the light of the experience gleaned on the occasion of the present study, certain improvements to the method might also be suggested. Firstly, the delineation of 5 categories of abundance of $C$. amentacea could be usefully simplified into only 2 or 3 categories, as already suggested by Nikolić et al. (2013). Secondly, it might seem logical to lessen

Table 3

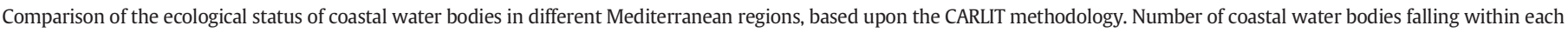
category (high through bad).

\begin{tabular}{|c|c|c|c|c|c|c|c|}
\hline Study area & High & Good & Moderate & Poor & Bad & Total & Reference \\
\hline District of Vlora (Albania) & 2 & 0 & 1 & 1 & 1 & 5 & This study \\
\hline Alboran Sea (Andalusia, Spain) & 11 & 6 & 2 & 1 & 0 & 20 & Bermejo et al., 2013 \\
\hline Catalonia (Spain) & 5 & 9 & 15 & 4 & 0 & 33 & Ballesteros et al., 2007 \\
\hline France, including Corsica & 19 & 9 & 7 & 2 & 0 & 37 & Blanfuné et al., 2011 \\
\hline Genova-Portofino area (Liguria, Italy) & 1 & 1 & 1 & 0 & 0 & 3 & Mangialajo et al., 2007 \\
\hline Capo Carbonara MPA (Sardinia) & 2 & 0 & 0 & 0 & 0 & 2 & Ferrigno et al., 2014 \\
\hline Malta & 7 & 1 & 1 & 0 & 0 & 9 & Blanfuné et al., 2011 \\
\hline Eastern Adriatic Sea (Croatia) ${ }^{a}$ & 4 & 0 & 0 & 1 & 1 & 6 & Nikolić et al., 2013 \\
\hline
\end{tabular}

\footnotetext{
a According to the Ballesteros et al. (2007) method, slightly modified.
} 
the weight of $C$. amentacea within the index calculation, in light of the fact that the species is less sensitive to water pollution than previously assumed (Thibaut et al., 2014; but see comments below). Thirdly, the presence of $L$. byssoides rims seems to be overweighted, and their death by submersion could be wrongly attributed to a decline in ecological quality, while actually due to the rise in sea level (Faivre et al., 2013; Thibaut et al., 2013). These suggestions, at a broader geographic range (the Adriatic and the Western Mediterranean Basin), will be the subject of further studies.

As regards the weigh, possibly too high, of $C$. amentacea within the CARLIT index calculation, it should be considered that the WFD uses the assemblage/habitats/species as indicators of water quality. The WFD says that water quality has to be high enough to not modify the species diversity, functionality and the habitats in the water body. If these three parameters are indistinguishable between a given place and a reference site (i.e. a place where human disturbances are nil or kept at a minimum), and the bioindicators used (in this case macroalgae of the habitats constituted by them) show no differences, it means that the water quality is not affecting the assemblages/habitats, and thus, this is consistent with the aims of the WFD. In this case, there would be no need to downweight the value of $C$. amentacea as the habitat remains unmodified in relation to a pristine place (Enric Ballesteros, pers. comm.). Furthermore, the article that claims that $C$. amentacea is less sensitive to pollution than previously expected (Thibaut et al., 2014) does not provide nutrient or pollution data. Finally, several papers unequivocally relate the effects of increased pollution values with the decline of $C$. mediterranea (the vicariant species of $C$. amentacea in some areas of the Mediterranean Sea) (Arévalo et al., 2007; Pinedo et al., 2007, 2015).

At present, the Sazani Island-Karaburuni Peninsula MPA, established in 2010, is not yet managed as an MPA. The management plan and its implementation are just at their very inception, so that the present study may represent a useful tool to support the implementation of the management plan and as a baseline for future comparisons.

\section{Acknowledgements}

This work was funded by the French Coastal Protection Agency (Conservatoire de l'Espace Littoral et des Rivages Lacustres; in short: Conservatoire du Littoral) within the framework of the Mediterranean Small Islands Initiative PIM. Thanks are due to Michael Paul, an English native speaker, for proof-reading the English and to an anonymous reviewer for valuable comments and suggestions.

\section{Appendix A. Supplementary data}

Supplementary data to this article can be found online at http://dx. doi.org/10.1016/j.marpolbul.2016.05.041.

\section{References}

Antolić, B., Špan, A., Žuljević, A., Nikolić, V., Grubelić, I., Despalatović, M., Cvitković, I., 2010. A checklist of the benthic marine macroalgae from the eastern Adriatic coast: II. Heterokontophyta: Phaeophyceae. Acta Adriat. 51 (1), 9-33.

Ar Gall, E., Le Duff, M., Sauriau, P.G., De Casamajor, M.N., Gevaert, F., Poisson, E., Hacquebart, P., Joncourt, Y., Barillé, A.L., Buchet, R., Bréret, M., Miossec, L., 2016. Implementation of a new index to assess intertidal seaweed communities as bioindicators for the European Water Framework Directory. Ecol. Indic. 60, 162-173.

Arévalo, R., Pinedo, S., Ballesteros, E., 2007. Changes in the composition and structure of Mediterranean rocky-shore communities following a gradient of nutrient enrichment: descriptive study and test of proposed methods to assess water quality regarding macroalgae. Mar. Pollut. Bull. 55, 104-113.

Ballesteros, E., 1984. 36. Els estatges supralitoral i mediolitoral de les illes Medes. In: Ros, J., Olivella, I., Gili, J.M. (Eds.), Els sistemes naturals de les illes Medes. Institut d'Estudis Catalans, Barcelona, Spain 647-658 pp.

Ballesteros, E., 1988. Estructura y dinámica de la comunidad de Cystoseira mediterranea Sauvageau en el Mediterráneo Noroccidental. Investig. Pesq. 52, 313-334.

Ballesteros, E., 1990a. Structure and dynamics of the community of Cystoseira zosteroides (Turner) C. Agardh (Fucales, Phaeophyceae) in the Northwestern Mediterranean. Sci. Mar. 54, 217-299.
Ballesteros, E., 1990b. Structure and dynamics of the Cystoseira caespitosa Sauvageau (Fucales, Phaeophyceae) community in the North-Western Mediterranean. Sci. Mar. $54,155-168$.

Ballesteros, E., Torras, X., Pinedo, S., Garcia, M., Mangialajo, L., de Torres, M., 2007. A new methodology based on littoral community cartography for the implementation of the European Water Framework Directive. Mar. Pollut. Bull. 55, 172-180.

Barcelona Convention, 1976. Convention de Barcelone. du 16 Février 1976 pour la protection de la mer Méditerranée et son protocole relatif à la prévention de la pollution de la mer Méditerranée par les opérations d'immersion effectuées par les navires et aéronefs.

Barcelona Convention, 1996. Annexe II -Protocole relatif aux aires spécialement protégées et à la diversité biologique en Méditerranée - annexes adoptées à Monaco le 24 novembre 1996. http://www.legifrance.gouv.fr/affichTexte.do? cidTexte $=$ JORFTEXT000000416310\&categorieLien $=$ cid.

Bellan-Santini, D., 1966. Influence des eaux polluées sur la flore et la faune marines benthiques dans la région marseillaise. Tech. Sci. Munic. 61 (7), 285-292.

Bellan-Santini, D., 1968. Conclusions d'une étude quantitative dans la biocoenose des algues photophiles en Méditerranée sur les côtes de Provence (France). Mar. Biol. 1 (3), 250-256

Bermejo, R., Vergara, J.J., Hernández, I., 2012. Application and reassessment of the reduced species list index for macroalgae to assess the ecological status under the Water Framework Directive in the Atlantic coast of Southern Spain. Ecol. Indic. 12 (1), 46-57.

Bermejo, R., de la Fuente, G., Vergara, J.J., Hernández, I., 2013. Application of the CARLIT index along a biogeographical gradient in the Alboran Sea (European Coast). Mar. Pollut. Bull. 72 (1), 107-118.

Bianchi, C.N., Morri, C., 2000. Marine biodiversity of the Mediterranean Sea: situation, problems and prospects for future research. Mar. Pollut. Bull. 40 (5), 367-376.

Bianchi, C.N., Corsini-Foka, M., Morri, C., Zenetos, A., 2014. Thirty years after: dramatic changes in the coastal marine habitats of Kos Island (Greece), 1981-2013. Mediterr. Mar. Sci. 15 (3), 482-497.

Bianconi, C.H., Boudouresque, C.F., Meinesz, A., Di Santo, F., 1987. Cartographie de la répartition de Lithophyllum lichenoides (Rhodophyta) dans la Réserve naturelle de Scandola (côte occidentale de Corse, Méditerranée). Travaux Scientifiques du Parc Naturel Régional et des Réserves Naturelles de Corse 13, pp. 41-63.

Blanc, J.J., Molinier, R., 1955. Les formations organogènes construites superficielles en Méditerranée occidentale. Bull. Inst. Océanogr. Monaco 1067, 1-26.

Blanfuné, A., Markovic, L., Thibaut, T., 2011. Assessment of the CARLIT methodology in the Mediterranean rocky water bodies. J. Phycol. 46, 173.

Boudouresque, C.F., 1971a. Contribution à l'étude phytosociologique des peuplements algaux des côtes varoises. Vegetatio 22 (1-3), 83-184.

Boudouresque, C.F., 1971b. Recherches de bionomie analytique, structurale et expérimentale sur les peuplements benthiques sciaphiles de Méditerranée occidentale (fraction algale). La sous-strate sciaphile des peuplements de grandes Cystoseira de mode battu. Bulletin du Museum d'Histoire Naturelle de Marseille 31 pp. $141-151+1$ Tabl.

Boudouresque, C.F., 2003. The erosion of Mediterranean biodiversity. In: RodríguezPrieto, C., Pardini, G. (Eds.), The Mediterranean Sea: An Overview of its Present State and Plans for Future Protection. Servei de Publicacions de la Universitat de Girona, Spain 53-112 pp.

Boudouresque, C.F., 2004. Marine biodiversity in the Mediterranean: status of species, populations and communities. Scientific Report of Port-Cros National Park 20, pp. 97-146.

Boudouresque, C.F., Verlaque, M., 2002. Biological pollution in the Mediterranean Sea: invasive versus introduced macrophytes. Mar. Pollut. Bull. 44, 32-38.

Boudouresque, C.F., Verlaque, M., 2013. Paracentrotus lividus. In: Lawrence, J.M. (Ed.), Sea Urchins: Biology and Ecology, third ed. Elsevier publ, Amsterdam, pp. 297-327.

Bressan, G., Babbini, L., Ghirardelli, L., Basso, D., 2001. Bio-construction and bio-destruction of Corallinales in the Mediterranean Sea. Biol. Mar. Mediterr. 8 (1), 131-174.

Buia, M.C., Porzio, L., Paolo Patti, F., 2007. The application of the "Carlit method" to assess the ecological status of coastal waters in the gulf of Naples. In: Pergent-Martini, C., E Asmi, S., Le Ravallec, C. (Eds.), Proceedings of the 3nd Mediterranean Symposium on Marine Vegetation, Marseille 27-29March 2007. Rac/Spa publi, Tunis, pp. 253-254.

Büttner, G., Feranec, J., Jaffrain, G., Mari, L., Maucha, G., Soukup, T., 2004. The CORINE land cover 2000 project. EARSeL eProceedings 3(3), pp. 331-346.

Cánovas-Molina, A., Montefalcone, M., Bavestrello, G., Cau, A., Bianchi, C.N., Morri, C. Carnese, S., Bo, M., 2016. A new ecological index for the status of mesophotic megabenthic assemblages in the Mediterranean based on ROV photography and video footage. Cont. Shelf Res. (in press)

Cavallo, M., Torras, X., Mascaró, O., Ballesteros, E., 2016. Effect of temporal and spatial variability on the classification of the ecological quality status using the CARLIT index Mar. Pollut. Bull. 102, 122-127.

Coll, M., Piroddi, C., Steenbeek, J., Kaschner, K., Lasram, F.B.R., et al., 2010. The biodiversity of the Mediterranean Sea: estimates, patterns, and threats. PLoS ONE 5 (8), e11842.

Coll, M., Piroddi, C., Albouy, C., Ben Rais Lasram, F., Cheung, W.W., Christensen, V., Karpuzi, V.S., Guilhaumon, F., Mouillot, D., Paleczny, M., Palomares, M.L., Steenbeek, J., Trujillo, P., Watson, R., Pauly, D., 2012. The Mediterranean Sea under siege: spatial overlap between marine biodiversity, cumulative threats and marine reserves. Glob. Ecol Biogeogr. 21, 465-480.

CORINE land cover, 2006. http://www.statistiques.developpement-durable.gouv.fr donnees-ligne/li/1825.html (accessed 20 March 2015).

Council of Europe, 1979. Convention de Berne - Convention relative à la conservation de la vie sauvage et du milieu naturel de l'Europe. Série des traités européens/104. Strasbourg, Conseil de l'Europe.

Devescovi, M., Ozretić, B., Iveša, L., 2005. Impact of date mussel harvesting on the rocky bottom structural complexity along the Istrian coast (Northern Adriatic, Croatia). J. Exp. Mar. Biol. Ecol. 325, 134-145. 
E.C., 2000. Directive 2000/60/EC of the European Parliament and the Council establishing a framework for the Community action in the field of water policy. Legislative Acts and Other Instruments, ENV 221 CODEC 513, European Union.

Ercegović, A., 1952. Sur les Cystoseira adriatiques. Leur morphologie, écologie et évolution (in Croatian and French). Fauna et Flora Adriatica, Volumen 2, Institut za Oceanografiju i Ribarstvo FNR Jugoslavije publisher, Split 212 pp +30 plates +1 map.

Faivre, S., Bakran-Petricioli, T., Horvatinčić, N., Sironič, A., 2013. Distinct phases of relative sea level changes in the central Adriatic during the last 1500 years - influence of climatic variations? Palaeogeogr. Palaeoclimatol. Palaeoecol. 369, 163-174.

Falace, A., Alongi, G., Cormaci, M., Furnari, G., Curiel, D., Cecere, E., Petrocelli, A., 2010. Change in the benthic algae along the Adriatic Sea in the last three decades. Chem. Ecol. 26, 77-90.

Fanelli, G., Piraino, S., Belmonte, G., Geraci, S., Boero, F., 1994. Human predation along Apulian rocky coasts (SE Italy): desertification caused by Lithophaga lithophaga fisheries. Mar. Ecol. Prog. Ser. 110, 1-8.

Feldmann, J., 1937. Recherches sur la végétation marine de la Méditerranée. La Côte des Albères. Rev. Algol. 10, 1-339.

Ferrigno, F., Boi, S., Cinti, M., Paliaga, B., Guala, I., 2014. Spatial and temporal distribution of shallow algal communities in the marine protected area of Capo Carbonara (Sardinia). Biol. Mar. Mediterr. 21 (1), 257-258.

Flo, E., Camp, J., Garcés, E., 2011. Assessment pressure methodology land uses index (LUSI). Report BQE Phytoplankton. Work Document (MedGiG Meeting, Rome), Spain, Catalonia.

Fraschetti, S., Bianchi, C.N., Terlizzi, A., Fanelli, G., Morri, C., Boero, F., 2001. Spatial variability and human disturbance in shallow subtidal hard substrates assemblages: a regional approach. Mar. Ecol. Prog. Ser. 212, 1-12.

Fraschetti, S., Terlizzi, A., Guarnieri, G., Pizzolante, F., D'Ambrosio, P., Maiorano, P., Beqiraj, S., Boero, F., 2011. Effects of unplanned development on marine biodiversity: a lesson from Albania (central Mediterranean Sea). J. Coast. Res. Spec. Issue 58, 106-115.

Galil, B.S., 2000. A sea under siege - alien species in the Mediterranean. Biol. Invasions 2 , 177-186.

Giaccone, G., Alongi, G., Cossu, A.V.L., Di Geronimo, R., Serio, D., 1993. La Vegetazione marina bentonica nel Mediterraneo: 1: sopralitorale e mesolitorale: proposte di aggiornamento. Bull. Acad. Gioen. Sci. Nat. 26 (341), 245-291.

Giaccone, G. Alongi, G., Pizzuto, F., Cossu, A., 1994. La Vegetazione marina bentonica fotofila del Mediterraneo: 2: Infralitorale e Circalitorale: proposte di aggiornamento. Bull. Acad. Gioen. Sci. Nat. 27 (346), 111-157.

Giakoumi, S., Halpern, B.S., Michel, L.N., Gobert, S., Sini, M., Boudouresque, C.F., Gambi, M.C., Katsanevakis, S., Lejeune, P., Montefalcone, M., Pergent, G., Pergent-Martini, C. Sanchez-Jerez, P., Velimirov, B., Vizzini, S., Abadie, A., Coll, M., Guidetti, P., Micheli, F., Possingham, H.P., 2015. Towards a framework for assessment and management of cumulative human impacts on marine food webs. Conserv. Biol. http://dx.doi. org/10.1111/cobi.12468

Gobert, S., Sartoretto, S., Rico-Raimondino, V., Andral, B., Chery, A., Lejeune, P., Boissery, P. 2009. Assessment of the ecological status of Mediterranean French coastal waters as required by the Water Framework Directive using the Posidonia oceanica Rapid Easy Index: PREI. Mar. Pollut. Bull. 58 (11), 1727-1733.

Guidetti, P., Boero, F., 2004. Desertification of Mediterranean rocky reefs caused by datemussel, Lithophaga lithophaga (Mollusca: Bivalvia), fishery: effects on adult and juvenile abundance of a temperate fish. Mar. Pollut. Bull. 48, 978-982.

Guiry, M.D., Guiry, G.M., 2015. 2015 AlgaeBase. World-Wide Electronic Publication. National University of Ireland, Galway http://www.algaebase.org; searched on 17 June 2015

Halpern, B.S., Walbridge, S., Selkoe, K.A., Kappel, C.V., Micheli, F., d'Agrosa, C., et al., 2008. A global map of human impact on marine ecosystems. Science 319 (5865), 948-952.

Harmelin, J.G., Sartoretto, S., Francour, P., 1996. Patrimoine biologique marin de l'archipe de Riou: première évaluation. Ville de Marseille publisher, Marseille 86 pp.

INSTAT, 2008. Albania in figures 2007. Tirana, Albania. Institute of Statistic 61p. http:// www.instat.gov.al/ (accessed September 23, 2010).

Janssens, M., Hoffmann, L., Demoulin, V., 1993. Cartographie des macroalgues dans la region de Calvi (Corse): comparaison après 12 ans (1978-79, 1990-91). Lejeunia 141, $1-62$.

Kashta, L., 1986. Alga makrofite detare të Shqipërisë Doctoral theses Sciences, Tirana University, Fac. Nat. 187 pp.

Kashta, L., 1992. Data on the Albanian Marine Flora. Rapports et PV de la Commission Internationale pour l'Exploration Scientifique de la Méditerranée 33, p. 349.

Kashta, L., 1995-1996. About distribution and ecology of Fucus virsoides along the Albanian coast. Buletin I Universitetit Shtetëror të Tiranë. Seria Shkencat Natyrore 48 (1), pp. 60-65 (in Albanian).

Kashta, L., Beqiraj, S., Tilot, V., Zuna, V., Dodbiba, E., 2011. The first MPA in Albania, Sazan island - Karaburini peninsula, as a regional priority conservation area for marine biodiversity. Var. Narave. 1, 139-158

Kupe, L., Miho, A., 2006. Considerations about environmental state of important aquatic habitats in Albania based in algal assessment - a review. Proceedings of RiverNet Conference, Tirana, Albania, pp. 1-9.

Laborel, J., 1987. Marine biogenic constructions in the Mediterranean, a review. Scientific Reports Port-Cros National Park 13, pp. 97-126.

Laborel, J., Laborel-Deguen, F., 1996. Biological indicators of Holocene sea-level and climatic variations on rocky coasts of tropical and subtropical regions. Quat. Int. 31 23-60.

Laborel, J., Delibrias, G., Boudouresque, C.F., 1983. Evidence of recent changes of sea-leve at Port-Cros Island (Western Mediterranean) from the study of an intertidal algal construction (Variations récentes du niveau marin à Port-Cros (Var, France), mises en évidence par l'étude de la corniche à Lithophyllum lichenoides). Comptes Rendus Hebdomadaires des Séances de l'Académie des Sciences 297, pp. 157-160.
Laborel, J., Morhange, C., Laborel-Deguen, F., 1993. Dégradation récente des formations construites superficielles à Lithophyllum lichenoides Philippi dans la réserve marine de Scandola. Travaux Scientifiques du Parc Naturel et Régional et des Réserves Naturelles de Corse 41, pp. 19-23.

Laborel, J., Boudouresque, C.F., Laborel-Deguen, F., 1994a. Les bioconcrétionnements littoraux de Méditerranée. In: Bellan-Santini, D., Lacaze, J.C., Poizat, C. (Eds.), Les biocénoses marines et littorales de Méditerranée, synthèse, menaces et perspectives. Muséum National d'Histoire Naturelle Publ., Paris, France 88-97 pp.

Laborel, J., Morhange, C., Lafont, R., Le Campion, J., Laborel-Deguen, F., Sartoretto, S., $1994 \mathrm{~b}$. Biological evidence of sea-level rise during the last 4500 years on the rocky coasts of continental southwestern France and Corsica. Mar. Geol. 120, 203-223.

Lejeusne, C., Chevaldonné, P., Pergent-Martini, C., Boudouresque, C.F., Pérez, T., 2010. Climate change effects on a miniature ocean: the highly diverse, highly impacted Mediterranean Sea. Trends Ecol. Evol. 25 (4), 250-260.

Ling, S.D., Scheibling, R.E., Rassweiler, A., Johnson, C.R., Shears, N., Connell, S.D., Salomon, A.K., Norderhaug, K.M., Péres-Matus, A., Hernández, J.C., Clemente, S., Blamey, L.K., Hereu, B., Ballesteros, E., Sala, E., Garrabou, J., Cebrian, E., Zabala, M., Fujita, D., Johnson, L.E., 2015. Global regime shift of catastrophic sea urchin overgrazing. Philos. Trans. R. Soc. B 370, 20130269.

Lotze, H.K., Lenihan, H.S., Bourque, B.J., Bradbury, R.H., Cooke, R.G., Kay, M.C., Kidwell, S.M., Kirby, M.X., Peterson, C.H., Jackson, J.B., 2006. Depletion, degradation, and recovery potential of estuaries and coastal seas. Science 312 (5781), 1806-1809.

Mačić, V., 2006. Distribution of seaweed Fucus virsoides J. Agardh in Boka Kotorska Bay (South Adriatic Sea). Annales Series Historia Naturalis 16, pp. 1-4

Maiorano, P., Mastrototaro, F., Beqiraj, S., Costantino, G., Kashta, L., Gherardi, M., Sion, L., D'Ambrosio, P., Carlucci, R., D'Ongia, G., Tursi, A., 2011. Bioecological study of the benthic communities on soft bottom of the Vlora Gulf (Albania). J. Coast. Res. Spec. Issue $58,95-105$.

Mangialajo, L., Ruggieri, N., Asnaghi, V., Chiantore, M., Povero, P., Cattaneo-Vietti, R., 2007. Ecological status in the Ligurian Sea: the effect of coastline urbanisation and the importance of proper reference sites. Mar. Pollut. Bull. 55 (1), 30-41.

Molinier, R., 1958. Etude des biocénoses marines du Cap Corse. Thèse Doctorat, Marseille.

Molinier, R., 1960. Etude des biocénoses marines du Cap Corse. Vegetatio 9 (4-5), 217-312.

Monbailliu, X., Torre, A., 1990. Plano di gestione integrata delle risorse naturali dell'Isola dell'Asinara. MedmaravisPubl 153 pp.

Morhange, C., 1994. La mobilité récente des littoraux provençaux (The recent mobility of the Provencal littoral). Thèse de doctorat en Géographie Physique. Université de Provence, Centre d'Aix, Faculté des Lettres et des Sciences Humaines, Institut de Geography, France (202 pp).

Morhange, C., Laborel-Deguen, F., Sartoretto, S., Laborel, J., 1992. Recherches sur les bioconstructions à Lithophyllum lichenoides en Méditerranée occidentale. Méditerranée 3-4, 64-71.

Munda, I.M., 1972. Seasonal and ecologically conditioned variations in the Fucus virsoides association from the Istrian coast (northern Adriatic). Dissertations Sazu Ljubjana 15, pp. 1-33.

Nicholls, R.J., Cazenave, A., 2010. Sea level rise and its impact on coastal zones. Science 328 (5985), 1517-1520.

Nikolić, V., Žuljević, A., Mangialajo, L., Antolić, B., Kušpilić, G., Ballesteros, E., 2013. Cartography of littoral rocky-shore communities (CARLIT) as a tool for ecological quality assessment of coastal waters in the Eastern Adriatic Sea. Ecol. Indic. 34, 87-93.

Ollivier, G., 1929. Etude de la flore marine de la Côte d'Azur. Annales de l'Institut Océanographique de Paris 7 (3), pp. 53-173.

Omrane, A., Guellouiz, S., Zarrouk, A., Romdhane, M.S., 2010. Assessment of the ecological status of the Galite island coastal waters (northern of Tunisia) using the "CARLIT" method. In: El Asmi, S., Langar, H., Belgacem, W. (Eds.), Proceedings of the 4th Mediterranean Symposium on Marine Vegetation (Yasmine-Hammamet, 2-4 December 2010). RAC/SPA publ., Tunis, pp. 204-206.

Orfanidis, S., Panayotidis, P., Stamatis, N., 2003. An insight to the ecological evaluation index (EEI). Ecol. Indic. 3, 27-33.

Orlić, M., Gačić, M., La Violette, P.E., 1992. The currents and circulation of the Adriatic Sea. Oceanol. Acta 15 (2), 109-124.

Pérès, J.M., 1982. In: Kinne, O. (Ed.), Zonations 5 (1). John Wiley \& sons Ltd publ., Marine Ecology, Chichester, England, pp. 9-45.

Picard, J., 1954. Modifications saisonnières des peuplements de l'horizon inférieur de la roche littorale. Comptes rendus hebdomadaires des séances de l'Académie des Sciences 238 (12), pp. 1358-1359.

Pignatti, S., 1962. Associazioni di alghe marine sulla costa veneziana. Memorie del Reale Istituto Veneto di Scienze, Lettere ed Arti Italy 32, pp. 1-134.

Pinedo, S., García, M., Satta, M.P., de Torres, M., Ballesteros, E., 2007. Rocky-shore communities as indicators of water quality: a case study in the Northwestern Mediterranean. Mar. Pollut. Bull. 55, 126-135.

Pinedo, S., Arévalo, R., Ballesteros, E., 2015. Seasonal dynamics of upper sublittoral assemblages in Mediterranean rocky shores along a eutrophication gradient. Estuar. Coast. Shelf Sci. 161, 93-101.

Ribera, M.A., Gomez-Garreta, A., Gallardo, T., Cormaci, M., Furnari, G., Giaccone, G., 1992. Check-list of Mediterranean seaweeds. I. Fucophyceae (Warming, 1884). Bot. Mar. $35,109-130$

Riggio, S., Calvo, S., Frada-Orestano, C., Chemello, R., Arculeo, M., 1994. La dégradation du milieu dans le golfe de Palerme (Sicile Nord-Ouest) et les perspectives d'assainissement. Actes du colloque scientifique Okéanos 'Pour qui la Méditerranée au $21^{\circ}$ siècle? Villes des rivages et environnement littoral en Méditerranée'. Okeanos Publ, Montpellier 82-89 pp.

Sala, E., Boudouresque, C.F., Harmelin-Vivien, M., 1998. Fishing, trophic cascades and the structure of algal assemblages: evaluation of an old but untested paradigm. Oikos 82, 425-439. 
Sala, E., Ballesteros, E., Dendrinos, P., Di Franco, A., Ferretti, F., Foley, D., Fraschetti, S., Friedlander, A., Garrabou, J., Güçlüsoy, H., Guidetti, P., Halpern, B.J., Hereu, B., Karamanlidis, A.A., Kizilkaya, Z., Macpherson, E., Mangialajo, L., Mariani, S., Micheli, F., Pais, A., Riser, K., Rosenberg, A.A., Sales, M., Selkoe, K.A., Starr, R., Tomas, F. Zabala, M., 2012. The structure of Mediterranean reef ecosystems across environmental and human gradients, and conservation implications. PLoS ONE 7 (2), 1-13.

Sauvageau, C., 1912. A propos des Cystoseira de Banyuls et de Guéthary. Bull. Station Biol. Arc. $14,1-424$

Sfriso, A., Facca, C., 2011. Macrophytes in the anthropic constructions of the Venice littorals and their ecological assessment by an integration of the 'CARLIT' index. Ecol. Indic. 11 (3), 772-781.

Sfriso, A., Facca, C., Ghetti, P.F., 2007. Rapid Quality Index (R-MaQI), based mainly on macrophyte associations, to assess the ecological status of Mediterranean transitional environments. Chem. Ecol. 23 (6), 493-503.

Sicsic, M., 1967. Répartition des formations à base de Lithophyllum tortuosum (Esper) Foslie, le long du littoral rocheux de la presqu'île de Giens. Annales de la Société des Sciences Naturelles et d'Archéologie de Toulon et du Var. 19, 173-179.

Soltan, D., Verlaque, M., Boudouresque, C.F., Francour, P., 2001. Changes in macroalgal communities in the vicinity of a Mediterranean sewage outfall after the setting up of a treatment plant. Mar. Pollut. Bull. 42 (1), 59-70.

Steneck, R.S., 1998. Human influences on coastal ecosystems: does overfishing create trophic cascades? Trends Ecol. Evol. 13 (11), 429-430.

Thibaut, T., Blanfuné, A., 2014. Préfiguration du réseau macroalgues - Bassin Rhône Méditerranée Corse - Application de la Directive Cadre Eau - Rapport d'état écologique des masses d'eau - littoral rocheux méditerranéen français - réévaluation de 12 masses d'eau. Agence de l'Eau RMC and Université Nice Sophia Antipolis Publ., Nice 36 pp.

Thibaut, T., Hereu, B., Susini, M.L., Cottalorda, J.M., Mangialajo, L., Ballesteros, E., 2007. Preliminary report on the evolution of the populations of Fucales in the National Park of Port-Cros (France). Proceedings of the 3rd Mediterranean Symposium on Marine Vegetation. Marseille. RAC/SPA Publ., Tunis 185-189 pp.

Thibaut, T., Blanfuné, A., Verlaque, M., 2013. Mediterranean Lithophyllum byssoides (Lamarck) Foslie rims: chronicles of a death foretold. Rapports et PV de la Commission Internationale pour l'Exploration Scientifique de la Méditerranée 40, p. 656.

Thibaut, T., Blanfuné, A., Markovic, L., Verlaque, M., Boudouresque, C.F., PerretBoudouresque, M., Mačić, V., Bottin, L., 2014. Unexpected abundance and long-term relative stability of the brown alga Cystoseira amentacea, hitherto regarded as a threatened species, in the north-western Mediterranean Sea. Mar. Pollut. Bull. 89, 305-323.

Thibaut, T., Blanfuné, A., Boudouresque, C.F., Verlaque, M., 2015. Decline and local extinction of Fucales in the French Riviera: the harbinger of future extinctions? Mediterr. Mar. Sci. 16 (1), 206-224.
Tilot, V., Jeudy de Grissac, A., 1994. Diagnostic of the marine and coastal environment of northern and southern Albania. Dobbin Milus International/ Priority Actions Programme of UNEP/Mediterranean Action Plan Publ., Split 64 pp.

Torras, X., Pinedo, S., García, M., Weitzmann, B., Ballesteros, E., 2016. Environmental quality of Catalan coastal waters based on macroalgae: The interannual variability of CARLIT index and its ability to detect changes in anthropogenic Pressures over time. In: Munné, A., et al. (Eds.), Experiences from Ground, Coastal and Transitional Water.Quality Monitoring: The EU Water Framework Directive Implementation in the Catalan River Basin District (Part II)Handbook of Environmental Chemistry 43. Springer International publ., Switzerland, pp. 183-200.

UNEP/MAP, 2011. Review of the Methods, Criteria and Limit Values for the Assessment of Eutrophication (Biological Quality Element "Phytoplankton") as Developed in the Framework of the Intercalibration Exercise of the MED GIG (Mediterranean Eco-Region) Water Framework Directive 2000/60 EC, Athens 41 pp.

UNEP/MAP, 2012. State of the Mediterranean Marine and Coastal Environment. UNEP/ MAP - Barcelona Convention, Athens 96 pp.

Vergés, A., Alcoverro, T., Ballesteros, E., 2009. Role of fish herbivory in structuring the vertical distribution of canopy algae Cystoseira spp. in the Mediterranean Sea. Mar. Ecol. Prog. Ser. 375, 1-11.

Verlaque, M., 1987. Contribution à l'étude du phytobenthos d'un écosystème photophile thermophile marin en Méditerranée occidentale. Etude structurale et dynamique du phytobenthos et analyses des relations Faune-Flore PhD Thesis Université d'AixMarseille II, Marseille 389 pp.

Verlaque, M., 2010. Field-methods to analyse the condition of Mediterranean Lithophyllum byssoides (Lamarck) Foslie rims. Scientific Reports of Port-Cros National Park 24, pp. 185-196.

Waycott, M., Duarte, C.M., Carruthers, T.J., Orth, R.J., Dennison, W.C., Olyarnik, S., et al., 2009. Accelerating loss of seagrasses across the globe threatens coastal ecosystems. Proc. Natl. Acad. Sci. 106 (30), 12377-12381.

Worm, B., Barbier, E.B., Beaumont, N., Duffy, J.E., Folke, C., Halpern, B.S., et al., 2006. Impacts of biodiversity loss on ocean ecosystem services. Science 314 (5800), 787-790.

Lopez y Royo, C., Silvestri, C., Pergent, G., Casazza, G., 2009. Assessing human-induced pressures on coastal areas with publicly available data. J. Environ. Manag. 90, 1494-1501.

Zenetos, A., Gofas, S., Verlaque, M., Cinar, M.E., García Raso, J.E., Bianchi, C.N., Morri, C., Azzurro, E., Bilecenoglu, M., Froglia, C., Siokou, S., Violanti, D., Sfrison, A., San, Martín G., Giangrande, A., Katağan, T., Ramos-Esplá, A., Mastrototaro, F., Ocaña, O. Zingone, A., Gambi, M.C., Streftaris, N., 2010. Alien species in the Mediterranean Sea by 2010. A contribution to the application of European Union's Marine Strategy Framework Directive (MSFD). Part I. Spatial distribution. Mediterr. Mar. Sci. 11 (2), 381-493. 